\title{
AN EMPIRICAL STUDY OF VARIOUS FACTORS, INFLUENCING THE BEHAVIOR OF CONSUMERS TOWARDS FAST FOOD JOINTS IN INDIAN MARKET
}

\author{
Sugandha Agarwal \\ European International College, Abu Dhabi, UAE \\ E-mail: drsugandhaagarwaal@gmail.com \\ Rafika Ben Guirat \\ European International College, Abu Dhabi, UAE \\ E-mail: rafika.benguirat@eic.ac.ae \\ Submission: 05/04/2017 \\ Accept: 12/05/2017
}

\section{ABSTRACT}

The global markets have witnessed major shifts in the consumers' behavior that have been much influenced by the change of technology, innovation, research and development. The consumer's needs thus dynamically change in order to respond to the change in the social and business environment. The corporate and business strategies of companies thus being developed in the light of capitalizing the potential from the markets but however, how the customers would react to the products and services of companies in new and existing markets remain the major question.

Customers belonging to different age groups flock towards these outlets to satisfy their taste buds and hedonistic needs. Out of all the age groups, the youngsters are considered to be the primary target by the fast food service industry. Hence, these fast food services try to lure its customers through sensory appeals.

It is well known that organized fast food services have already made their presence felt in a big way in almost all the major cities of India. The fast food outlets attract customers with their blend of tasty food, Quality of food served, efficient service, appearance of staff, décor, general excitement a place generates and other aesthetic appeals. Organized as well as unorganized fast food service is a very fast growing industry in India especially in urban areas. 
INDEPENDENT JOURNAL OF MANAGEMENT \& PRODUCTION (IJM\&P)

http://www.ijmp.jor.br

v. 8 , n. 4, October - December 2017

ISSN: 2236-269X

DOI: 10.14807/ijmp.v8i4.657

The aim of this study is to investigate the factors that are influencing consumer behavior towards fast food joints present in unorganized form in India. It further aims to examine major growth drivers of fast food services in the market and the demographic profile of consumers of fast food services. This study aims to analyze that amount spent per visit to a fast food joint relates to the occupations and the income of customers. And the frequency of visiting fast food joints and preparation served at fast food joints are whether influenced by the dietary preference of customers. Organizations must analyze the consumer behavior which is largely influenced by number of socio-cultural, demographic and psychological factors. To differentiate itself from others in the market, is the core purpose of organizations and to achieve this, an all-inclusive approach is essential to integrate all the crucial yet important factors that could improve the overall business strategy. Fast food joints realize the importance of factors that influence and affect the customer behavior and the potential of customer loyalty program in order to improve their brand image and company identity in the consumer market.

Keywords: consumer behavior, business strategies, socio-cultural factors, psychological factors, sensory appeals, demographic factors

\section{INTRODUCTION}

India is one of the most expeditious growing economies in the world. Driven by transmuting demographics, auxiliary and stable regime, propitious economic policies, and a positive sentiment that country's GDP is estimated to grow at 7.4 percent, as estimated by the International Monetary Fund (IMF), over the Fiscal year 017 (FY 17) and FY 18.

Relatively, the world economy is expected to grow at 3.1 percent over 2016, postulating unaffected trade ties between the European Coalescence (EU) and the Amalgamated Kingdom (U.K.). These projections make India the most expeditious growing astronomically immense economy world-wide. Similarly, India's magnification ratings by the 'Big Three' credit rating agencies depict a positive perspective as shown in the below-mentioned table.

\begin{tabular}{|c|c|c|}
\hline Agency/Organization & \multicolumn{2}{|c|}{ Growth Forecasts for India } \\
\hline & FY 17 & FY18 \\
\hline Fitch ratings & $7.7 \%$ & $7.9 \%$ \\
\hline Moody's investors service & $7.5 \%$ & $7.5 \%$ \\
\hline Standard \& Poor's & $8.0 \%$ & $8.0 \%$ \\
\hline
\end{tabular}


DOI: 10.14807/ijmp.v8i4.657

\begin{tabular}{|c|c|c|}
\hline IMF & $7.4 \%$ & $7.4 \%$ \\
\hline ADB (Asian Development Bank) & $7.4 \%$ & $7.8 \%$ \\
\hline
\end{tabular}

(Source: KPMG \& FCCI. (2016, November). India's food service industry : growth recipe : consumer market. Retrieve from https://assets.kpmg.com/content/dam/kpmg/in/pdf/2016/11/lndias-foodservice.pdf)

The Indian hospitality industry is one of the industries which contribute to country's growth with positive outlook. Major characteristics of the Indian hospitality industry are High seasonality, Labor intensive, Fragmented, Changing consumer dynamics and availability of easy finance.

Major characteristics of the Indian hospitality industry are High seasonality, Labor intensive, Fragmented, Changing consumer dynamics and availability of easy finance. The Indian hospitality industry is highly fragmented with a large number of small and unorganized players accounting for a lion's share. The country has experienced a change in consumption patterns.

The middle-class population with higher disposable incomes has caused the shift in spending pattern, with discretionary purchases forming a substantial part of total consumer spending. Increased affordability and affinity for leisure travel are driving tourism in India and in turn aiding growth of the hospitality industry. Emergence of credit culture and easier availability of personal loans have also driven growth in the travel and tourism and hospitality industries in the country.

The Indian hospitality industry has emerged as one of the key industries driving growth of the services sector in India. It has evolved into an industry that is sensitive to the needs and desires of people. The fortunes of the hospitality industry have always been linked to the prospects of the tourism industry and tourism is the foremost demand driver of the industry.

The Indian hospitality industry has recorded healthy growth fueled by robust inflow of foreign tourists as well as increased tourist movement within the country and it has become one of the leading players in the global industry.

Fast Food Industry in India became the fastest growing industry in the last decade when number of international companies entered the market in order to expand their market share and area of operations.

However, the major challenges that appeared amongst the retailers were cultural barriers, difference in eating habits and religious barriers whereas unawareness, low spending power was others. However, with the advent of 
INDEPENDENT JOURNAL OF MANAGEMENT \& PRODUCTION (IJM\&P)

http://www.ijmp.jor.br

v. 8, n. 4, October - December 2017

ISSN: 2236-269X

DOI: 10.14807/ijmp.v8i4.657

Globalization and Liberalization of economy, major changes were noticed in terms of education level, employment, and savings and GDP rate in the economy.

This led to more purchasing power in the consumers that began to try the new consumer durables and eat outplaces in metro cities and towns. This also impacted on the sales and growth of fast food retailers who developed their customer relationship strategy and marketing mix more often to gain competitive advantage in the markets.

As a result, the domestic and international retailers spread their operations to major cities and towns across the country in a short period of time, however still there was difference in the marketing strategy of international retailers in terms of marketing initiatives they launched in the western countries.

The research study thus focused on exploring theories and models of consumer behavior, scope of customer loyalty and customer relationship strategy and effectiveness of marketing strategies of domestic and international retailers in the market. The Indian fast food habits and the customer perception towards fast food has noticed gradual shift in the recent years as the significant portion of the population spent more money on eating fast food from the domestic and international retailers in the market.

The sector was once unnoticed and merely had any existence in the food and hospitality industry but recent findings suggested that there is huge potential in the sector as the growth rate was recorded above $30 \%$ in the recent years. The major international players including Kentucky Fried Chicken, McDonalds, Pizza Hit, and Dominos' entered the Indian market in the last decade.

As per the KPMG and FICCl report, 2016, the Indian Food and Beverage (F\&B) services industry is one the most vibrant industries to witness rapid and unprecedented growth over the recent past. The industry contributes significantly to the nation's economy and has been the frontrunner in terms of attracting investments.

'The Gross Value Added (GVA) by Hotels and restaurants has witnessed an annual increase in both absolute and relative terms. It grew from INR 1,084.2 billion in FY14 to INR 1,211.7 billion in FY 15, growing its contribution in country's overall GVA from $1 \%$ in FY 14 to 1.1\% in FY15' (source: press notes on First Revised 
Estimates of National Income, Consumption Expenditure, Savings and Capital Formation 2014-2015, CSO-MoSPI, January 2016).

According to National Restaurant Association of India (NRAI), 'the restaurant industry is expected to contribute about 2.1 percent to the total GDP of India by 2021' (source: NRAI India Food Services Report 2016 launched by Shri Amitabh Kant in New Delhi, NRAl websites, 21/07/2016). Food expenditure constitutes a majority of population's consumption basket and the share is expected to grow further in the coming years.

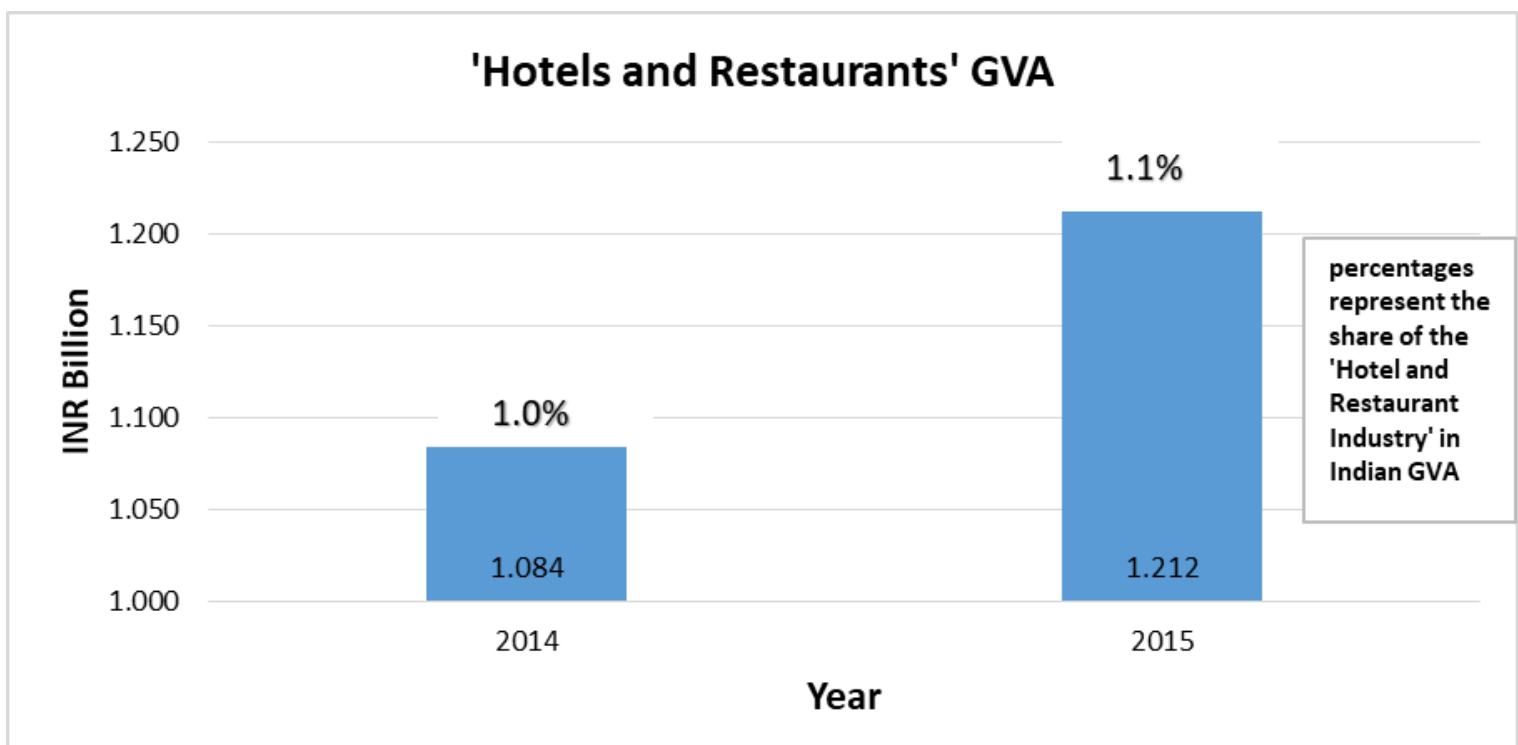

(Source: KPMG \& FCCI. (2016, November). India's food service industry: growth recipe : consumer market. Retrieve from https://assets.kpmg.com/content/dam/kpmg/in/pdf/2016/11/lndias-foodservice.pdf)

\subsection{Factors Influencing Consumer's Behavior}

Consumer behavior refers to the selection, purchase and consumption of goods and services for the satisfaction of their wants. After selecting the commodities, the consumer makes an estimate of the available money which he can spend. Lastly, the consumer analyzes the prevailing prices of commodities and takes the decision about the commodities he should consume. Meanwhile, there are various other factors influencing the purchases of consumer such as social, cultural, personal and psychological. 




\subsection{Cultural factors}

Consumer behavior is deeply influenced by cultural factors such as: buyer culture, subculture, and social class.

Culture: Basically, culture is the part of every society and is the important cause of person wants and behavior. The influence of culture on buying behavior varies from country to country therefore marketers have to be very careful in analyzing the culture of different groups, regions or even countries.

Subculture: Each culture contains different subcultures such as religions, nationalities, geographic regions, racial groups etc. Marketers can use these groups by segmenting the market into various small portions. For example, marketers, can design products according to the needs of a particular geographic group.

Social Class: Every society possesses some form of social class which is important to the marketers because the buying behavior of people in a given social class is similar. In this way marketing activities, could be tailored according to different social classes. Here we should note that social class is not only determined by income but there are various other factors as well such as: wealth, education, occupation etc. 


\subsection{Social factors}

Social factors also impact the buying behavior of consumers. The important social factors are: reference groups, family, role and status.

Reference Groups: Reference groups have potential in forming a person attitude or behavior. The impact of reference groups varies across products and brands. For example, if the product is visible such as dress, shoes, car etc. then the influence of reference groups will be high. Reference groups also include opinion leader (a person who influences other because of his special skill, knowledge or other characteristics).

Family: Buyer behavior is strongly influenced by the member of a family. Therefore, marketers are trying to find the roles and influence of the husband, wife and children. If the buying decision of a particular product is influenced by wife, then the marketers will try to target the women in their advertisement. Here we should note that buying roles change with change in consumer lifestyles.

Roles and Status: Each person possesses different roles and status in the society depending upon the groups, clubs, family, organization etc. to which he belongs. For example, a woman is working in an organization as finance manager. Now she is playing two roles, one of finance manager and other of mother. Therefore, her buying decisions will be influenced by her role and status.

\subsection{Personal factors}

Personal factors can also affect the consumer behavior. Some of the important personal factors that influence the buying behavior are: lifestyle, economic situation, occupation, age, personality and self-concept.

Age: Age and life-cycle have potential impact on the consumer buying behavior. It is obvious that the consumers change the purchase of goods and services with the passage of time. Family life-cycle consists of different stages such young singles, married couples, unmarried couples etc. which help marketers to develop appropriate products for each stage.

Occupation: The occupation of a person has significant impact on his buying behavior. For example, a marketing manager of an organization will try to purchase 
INDEPENDENT JOURNAL OF MANAGEMENT \& PRODUCTION (IJM\&P)

http://www.ijmp.jor.br

v. 8, n. 4, October - December 2017

ISSN: 2236-269X

DOI: 10.14807/ijmp.v8i4.657

business suits, whereas a low-level worker in the same organization will purchase rugged work clothes.

Economic Situation: Consumer economic situation has great influence on his buying behavior. If the income and savings of a customer is high, then he will purchase more expensive products. On the other hand, a person with low income and savings will purchase inexpensive products.

Lifestyle: Lifestyle of customers is another important factor affecting the consumer buying behavior. Lifestyle refers to the way a person lives in a society and is expressed by the things in his/her surroundings. It is determined by customer interests, opinions, activities etc and shapes his whole pattern of acting and interacting in the world.

Personality: Personality changes from person to person, time to time and place to place. Therefore, it can greatly influence the buying behavior of customers. Actually, Personality is not what one wears; rather it is the totality of behavior of a man in different circumstances. It has different characteristics such as: dominance, aggressiveness, self-confidence etc. which can be useful to determine the consumer behavior for particular product or service.

\subsection{Psychological Factors}

There are four important psychological factors affecting the consumer buying behavior. These are: perception, motivation, learning, beliefs and attitudes.

Motivation: The level of motivation also affects the buying behavior of customers. Every person has different needs such as physiological needs, biological needs, social needs etc. The nature of the needs is that, some of them are most pressing while others are least pressing. Therefore, a need becomes a motive when it is more pressing to direct the person to seek satisfaction.

Perception: Selecting, organizing and interpreting information in a way to produce a meaningful experience of the world is called perception. There are three different perceptual processes which are selective attention, selective distortion and selective retention. In case of selective attention, marketers try to attract the customer attention. Whereas, in case of selective distortion, customers try to interpret the information in a way that will support what the customers already believe. Similarly, 
in case of selective retention, marketers try to retain information that supports their beliefs.

Beliefs and Attitudes: Customer possesses specific belief and attitude towards various products. Since such beliefs and attitudes make up brand image and affect consumer buying behavior therefore marketers are interested in them. Marketers can change the beliefs and attitudes of customers by launching special campaigns in this regard.

\section{REVIEW OF LITERATURE}

India has seen unprecedented growth and development in the fast food retailing in the recent years however this is also vested to the significant increase in the income level, influence of cultures, urbanization, globalization, changes in the lifestyles, family structures and social interaction among consumers.

Ling et al. (2004), Goyal and Singh (2007) emphasized that consumer buying behavior has been influenced by the gradual changes in the economic, social, psychological and cultural factors and moreover, the sustained development in the Indian market place has fueled the fast food sector because of its relative competitive advantage in comparison to other related sectors in the market.

Precisely, Mukherjee and Patel (2005) found that the customer perception has significantly improved with better eating experience they had at the stores that enormously changed their customer relationship strategy. The customers now have access to the fresh foods, variety of options with quick delivery at low prices. Wells et al. (2007) also found that customer preference has also changed towards packaged food in India as in the past there were merely few customers who tended to buy them.

However, the rising trend of fast food availability in the market, emerging culture, desire for affordable food and moreover, favorable eating experience has influenced the customers to try the different kinds of fast foods available in the market.

Sabnavis (2008) cited that consumers now made frequent visits to fast food chains in metro and urban cities in the country and moreover, the small cities and towns have also been looking forward to welcome the fast food retailers in their locations with the increased awareness among the public in the markets. 
Batte et al. (2007), Goyal and Singh (2007) believed that choice of fast food stores among Indians was largely influenced by their socio demographic characteristics such as disposable income level, family size, education level, cultural background, age factor, religion, etc. Significantly, the findings based on the survey conducted by Ali et al. (2010) on Buying Behaviour of Consumers in Emerging Economies found that consumers buying behaviour has been dynamically shifting and was highly influenced by the places of purchase, variety, price, attraction for children, entertainment features at stores and moreover intangible traits like hygienic food, quality, cleanliness, courtesy, convenience and effective customer services.

Sabnavis (2008) said that food consumption pattern in India has now shifted from fresh, unprocessed food to packaged, branded and processed food. The awareness and consciousness about the foods has also added advantage to the fast food industry. The metro and fast growing cities have noticed the fierce demand for fast food as multinational organizations attempted to improve their market share in the country.

The study conducted by Goyal and Singh (2007) on Consumer Behaviour of Fast Food Chains in India, found that consumers now wished to have more convenient place where they could go with their family to have good food while enjoying other features such as basic amenities, entertainment, customer services and other physical environmental features.

\subsection{Objectives of Study}

The objective of this study are to analyze the consumer's spending behavior on fast food consumption and their preference for fast food menu at fast food restaurants, to analyze the consumer's consumption expenditure towards fast food with respect to gender, age, income, education and dietary preference, to identify the determinants of changing preference towards fast food joints, to find out the factors influencing behavior of the consumers of fast food joints, to ascertain the factors, influence the purchase of fast food, to identify the overall satisfaction level among the customers of fast food joints. 


\subsection{Research Methodology}

Research is the systematic process of collecting and analyzing information (data) in order to increase our understanding of the phenomenon about which we are concerned or interested.

In other words, the search for knowledge through objective and systematic method of finding solution to a problem is research. According to Redman and Mory: "Research is a systematically effort to gain new knowledge".

The research design followed for this research work is initially exploratory study (which was used to understand the factors influencing the behaviour of the consumers at fast food joints with special reference to Nirula's) followed by descriptive in nature.

\subsection{Sources of data collection:}

For the purpose of the study the following sources of data are used:

Primary Data: It is collected afresh and for the first time, and thus happen to be original in character. This data was collected through questionnaires and interviews which were done while visiting the stores. Primary data was also collected from the feedback of customers of fast food joints with the help of questionnaire.

Secondary Data: It is that type of data which have already been collected by someone else and which have through some statistical analysis. This data was collected from websites, journals and periodicals, business magazines, books and past records of the organization. Secondary data was collected from internet, journals, and books and from company's employees.

\subsection{Sample design and size}

In this research work Judgemental Sampling method is used. It is a nonprobability sampling technique where the researcher selects units to be sampled based on their knowledge and professional judgment.

The sample population comprises of the customers who visited at different outlets of fast food joints in Delhi and National Capital Region (NCR) of India

Though the questionnaires were administered to 150 customers. However, due to incomplete responses and to eliminate biased factor, only 100 properly filled 
INDEPENDENT JOURNAL OF MANAGEMENT \& PRODUCTION (IJM\&P)

http://www.ijmp.jor.br

v. 8, n. 4, October - December 2017

ISSN: 2236-269X

DOI: 10.14807/ijmp.v8i4.657

and authentic questionnaires were used for analysing the data. Hence, 100 positive respondent customers are taken as the sample size for data analysis.

Sample unit: Customers of Fast Food Joints

Sampling technique: Judgmental \& Convenience sampling

Sampling size: 100 Questionnaires of 23 Questions each

Domain of study: DELHI /National Capital Region

Statistical tools: Percentage analysis, Chi-square test, Rank function, Mean and Standard Deviation, Tables, Bar graphs and Pie charts.

\section{DATA ANALYSIS \& INTERPRETATION}

Section 1: Demographic Profile of Respondents

\begin{tabular}{|c|c|c|c|}
\hline Variables & Group Variables & Frequency & Percentage (\%) \\
\hline \multirow{4}{*}{ Age } & Below 20 years & 8 & 8 \\
\hline & $21-30$ years & 60 & 60 \\
\hline & 31- 40 years & 28 & 28 \\
\hline & $41 \&$ above & 4 & 4 \\
\hline \multirow[b]{2}{*}{ Gender } & Male & 78 & 78 \\
\hline & Female & 22 & 22 \\
\hline \multirow{4}{*}{ Occupation } & Business & 28 & 28 \\
\hline & Service & 64 & 64 \\
\hline & Student & 6 & 6 \\
\hline & Homemaker & 2 & 2 \\
\hline \multirow{4}{*}{ Income } & Less than 20,000 INR & 18 & 18 \\
\hline & $20,000-40,000$ INR & 50 & 50 \\
\hline & $41,000-60,000$ INR & 8 & 8 \\
\hline & More than 60,000 INR & 24 & 24 \\
\hline \multirow{4}{*}{ Education } & Under graduate & 4 & 4 \\
\hline & Graduate & 24 & 24 \\
\hline & Post graduate & 66 & 66 \\
\hline & Above & 6 & 6 \\
\hline \multirow{3}{*}{$\begin{array}{c}\text { Dietary } \\
\text { preference }\end{array}$} & Veg & 36 & 36 \\
\hline & Non-veg & 16 & 16 \\
\hline & Both & 48 & 48 \\
\hline
\end{tabular}

Source: Author's own compilation from primary data

Statistical analysis helps to gauge that $50 \%$ of the people who have 20,000 40,000 income visit the fast food joints i.e. in a majority basis. $24 \%$ of the people who have more than 60,000 of income visit the stores, $18 \%$ of the people visit the stores who have less than 20,000 of income and only $8 \%$ of people used to visit the stores having 41000 to 60000 of income. 
INDEPENDENT JOURNAL OF MANAGEMENT \& PRODUCTION (IJM\&P)

http://www.ijmp.jor.br

v. 8, n. 4, October - December 2017

ISSN: 2236-269X

DOI: 10.14807/ijmp.v8i4.657

Table clearly depicts that majority of the people (60\%) who visit fast food joints belong to age bracket of 21-35 years. Statistics clearly indicates that people belonging to age bracket of below 20 years (8\%) and more than 50 years (8\%), rarely visit fast food joint. majority number of people which visits the fast food joints are Males having a score of $78 \%$ and rest $22 \%$ are the females. Majority of customers (64\%) of fast food joints are having Job as their primary occupation, whereas $2 \%$ and $6 \%$ customers are homemakers and students respectively. 28\% customers of fast food joints run their own business.

Thus, we can interpret that people doing job are fonder of visiting fast food joints. If we look at the educational profile of the respondents, we can easily interpret that majority of the respondents i.e. $66 \%$ who visit the fast food joints like fast food joints are post graduates. $24 \%$ customers of fast food joints are simply graduates whereas percentage of undergraduate customers is very low i.e. $4 \%$ only.

Dietary preference is one of the important Demographic criteria considered for analyzing the behavior of consumers towards fast food joints. Above drawn chart interprets that majority of the people (48\%) visiting fast food joints prefer both vegetarian as well as non-vegetarian food items, as compared to this, only $16 \%$ of the people are pure non-vegetarians.

Section 2: Analysis of Respondents' Responses - Frequency of visiting fast food joints?

\begin{tabular}{|c|c|}
\hline Attributes & Response in percentage (\%) \\
\hline Daily & $10 \%$ \\
\hline Weekly & $60 \%$ \\
\hline Monthly & $18 \%$ \\
\hline On special occasions/festivals & $12 \%$ \\
\hline Total & $100 \%$ \\
\hline
\end{tabular}

Source: authors own compilation from primary data

The above table shows that the majority (60\%) of respondents are visiting fast food joints weekly, $18 \%$ of total respondents are visiting fast food joints monthly,12\% of total respondents are visiting fast food joints on special occasions/festivals and only $10 \%$ of total respondents are visiting fast food joints on daily basis.

i. Enjoy visiting and spending time at fast food joints with whom.

\begin{tabular}{|c|c|}
\hline Attributes & Response in percentage (\%) \\
\hline Friends & $40 \%$ \\
\hline Family & $20 \%$ \\
\hline Relatives & $20 \%$ \\
\hline Alone & $6 \%$ \\
\hline
\end{tabular}


INDEPENDENT JOURNAL OF MANAGEMENT \& PRODUCTION (IJM\&P)

http://www.ijmp.jor.br

v. 8, n. 4, October - December 2017

ISSN: 2236-269X

DOI: 10.14807/ijmp.v8i4.657

\begin{tabular}{|c|c|}
\hline Colleague & $14 \%$ \\
\hline Total & $100 \%$ \\
\hline Source: authors own compilation from primary data
\end{tabular}

On the basis of the response and related analysis shows in above table the majority of respondents (40\%) confirmed that they visit fast food joints with their friends as compared to this only $20 \%$ of total respondents visit fast food joints with family and relatives, $14 \%$ of total respondents visit fast food joints with their colleagues and only $6 \%$ of total respondents visit fast food joints alone. So, it is evident that most of the time, people prefer to visit fast food joints with their friends probably considering it as an opportunity to hang out with them.

ii. $\quad$ Amount of money spent per visit to a fast food joint per head?

\begin{tabular}{|c|c|}
\hline Attributes & Response in percentage (\%) \\
\hline INR 200-500 & $22 \%$ \\
\hline INR 500-1000 & $42 \%$ \\
\hline Above & $36 \%$ \\
\hline Total & $100 \%$ \\
\hline
\end{tabular}

Source: authors own compilation from primary data

The statistical analysis of the above data reveals that the majority of respondents (42\%) spend between INR 500 and Rs1000, $36 \%$ of total respondents are spending above INR 1000 and only $22 \%$ of total respondents are spending amount between INR 200 and INR 500.

iii. Preferable time to visit a fast food joint?

\begin{tabular}{|c|c|}
\hline Attributes & Response in percentage (\%) \\
\hline Morning & $0 \%$ \\
\hline Afternoon & $46 \%$ \\
\hline Evening & $50 \%$ \\
\hline Late night & $4 \%$ \\
\hline Total & $100 \%$ \\
\hline \multicolumn{2}{|c|}{ Source: authors own compilation from primary data }
\end{tabular}

The above table shows that the majority of respondents with $50 \%$ prefer to visit fast food joints in the evening.46\% of total respondents prefer to visit fast food joints in afternoon and only $4 \%$ of total respondents prefer to visit fast food joints in late night. None of the respondents prefer to visit fast food joints in morning.

iv. How do customers get to know about different fast food joints?

\begin{tabular}{|c|c|}
\hline Attributes & Response in percentage (\%) \\
\hline Word of mouth & $20 \%$ \\
\hline Advertisements & $0 \%$ \\
\hline Attracted by food joints & $24 \%$ \\
\hline Visible outlets & $56 \%$ \\
\hline Total & $100 \%$ \\
\hline
\end{tabular}

Source: authors own compilation from primary data 
INDEPENDENT JOURNAL OF MANAGEMENT \& PRODUCTION (IJM\&P)

http://www.ijmp.jor.br

v. 8, n. 4, October - December 2017

ISSN: 2236-269X

DOI: 10.14807/ijmp.v8i4.657

The above data shows that the majority of respondents have come to know about fast food joints owing to its visible outlets, $24 \%$ of total respondents know variety of fast food joints due to their attraction towards food joints, $20 \%$ of total respondents have come to know owing to word of mouth. No respondent has given credit to advertisement for his knowledge about fast food joints.

v. Preference for vegetarian and non-vegetarian preparations served at fast food joints.

\begin{tabular}{|c|c|}
\hline Attributes & Response in percentage (\%) \\
\hline Veg & $38 \%$ \\
\hline Non-veg & $18 \%$ \\
\hline Both & $44 \%$ \\
\hline Total & $100 \%$ \\
\hline Source: authors own compilation from primary data
\end{tabular}

As per the analysis of the above table the majority of respondents with 44\%like both veg and non-veg preparations of food, 38\% of total respondents like preparation of veg foodandonly $18 \%$ of total respondents like preparation of non-veg food.

vi. Reasons for patronizing a particular fast food joint.

\begin{tabular}{|c|c|}
\hline Attributes & Response in percentage (\%) \\
\hline Quality & $36 \%$ \\
\hline Location & $50 \%$ \\
\hline Price & $6 \%$ \\
\hline Services & $8 \%$ \\
\hline Any other & $0 \%$ \\
\hline Total & $100 \%$ \\
\hline
\end{tabular}

Source: authors own compilation from primary data

As per the analysis of above table, the majority of respondents with $50 \%$ patronize a fast food joint because of its location, $36 \%$ of respondents due to its quality $8 \%$ for services and only $6 \%$ respondents for price. No other reason to patronize fast food joint was made evident by the respondents.

vii. According to customers which is the most effective promotional activity followed by fast food joints in general to attract the customers?

\begin{tabular}{|c|c|}
\hline Attributes & Response in percentage (\%) \\
\hline Discounts & $10 \%$ \\
\hline Home delivery & $42 \%$ \\
\hline Combo offers & $32 \%$ \\
\hline Any other & $16 \%$ \\
\hline Total & $100 \%$ \\
\hline
\end{tabular}

Source: authors own compilation from primary data 
INDEPENDENT JOURNAL OF MANAGEMENT \& PRODUCTION (IJM\&P)

http://www.ijmp.jor.br

v. 8, n. 4, October - December 2017

ISSN: 2236-269X

DOI: 10.14807/ijmp.v8i4.657

The above table shows that the majority of customers with $42 \%$ get attracted to fast food joints because of their home delivery promotional activity, $32 \%$ of respondents get attracted by the combo offers, $16 \%$ get attracted by some other medium and $10 \%$ of the customers are attracted by the discounts they offer.

viii. How do you perceive overall quality of services provided by fast food joints to its customer?

\begin{tabular}{|c|c|}
\hline Attributes & Response in percentage (\%) \\
\hline Excellent & $14 \%$ \\
\hline Very good & $22 \%$ \\
\hline Good & $42 \%$ \\
\hline Average & $16 \%$ \\
\hline Poor & $6 \%$ \\
\hline Total & $100 \%$ \\
\hline
\end{tabular}

Source: authors own compilation from primary data

As per the above data, the majority of customers i.e. $42 \%$ perceive the quality of food provided by fast food joints as good, $22 \%$ rate it as very good, $16 \%$ rate it as average, $14 \%$ rate it as excellent and only $6 \%$ rate it as poor.

ix. Does a customer believe in recommending his/her favorite fast food joint to others?

\begin{tabular}{|c|c|}
\hline Attributes & Response in percentage (\%) \\
\hline Yes & $70 \%$ \\
\hline No & $30 \%$ \\
\hline Total & $100 \%$ \\
\hline
\end{tabular}

Source: authors own compilation from primary data

The above table reveals that majority of customers i.e. $70 \%$ are positive about recommending to others but the rest $30 \%$ of customers are not in the favor of recommending to others.

Section 3: Ranking Analysis - Ranking the highest as least and lowest as a most important factor as per the respondents' view.

\begin{tabular}{|l|l|c|c|c|c|}
\hline $\begin{array}{c}\text { No. of } \\
\text { Attributes }\end{array}$ & \multicolumn{1}{|c|}{ Attributes } & Sum & \multicolumn{2}{|c|}{ Range } & $\begin{array}{c}\text { Ranking (highest as } \\
\text { least and lowest as a } \\
\text { most Important factor) }\end{array}$ \\
\cline { 3 - 6 } & & Scores & Min & max & $\begin{array}{l}\text { Rank on the basis of } \\
\text { sum of scores }\end{array}$ \\
\hline 1 & Taste of Food & 120 & 1 & 8 & 2 \\
\hline 2 & variety in menu & 111 & 1 & 8 & 1 \\
\hline
\end{tabular}


INDEPENDENT JOURNAL OF MANAGEMENT \& PRODUCTION (IJM\&P)

http://www.ijmp.jor.br

v. 8, n. 4, October - December 2017

ISSN: 2236-269X

DOI: 10.14807/ijmp.v8i4.657

\begin{tabular}{|l|l|c|c|c|c|}
\hline 3 & food quality & 181 & 1 & 11 & 3 \\
\hline 4 & Friendly, polite and Helpful staff & 376 & 1 & 12 & 7 \\
\hline 5 & Efficient service & 309 & 3 & 12 & 6 \\
\hline 6 & $\begin{array}{l}\text { Sympathetic handling of } \\
\text { complaints }\end{array}$ & 525 & 2 & 12 & 12 \\
\hline 7 & Décor & 261 & 1 & 12 & 4 \\
\hline 8 & Staff appearance & 414 & 2 & 12 & 9 \\
\hline 9 & $\begin{array}{l}\text { General Excitement a place } \\
\text { generates }\end{array}$ & 443 & 2 & 12 & 10 \\
\hline 10 & Location & 269 & 1 & 11 & 5 \\
\hline 11 & Seating capacity & 386 & 3 & 12 & 8 \\
\hline 12 & Waiting time for the order & 503 & 3 & 12 & 11 \\
\hline
\end{tabular}

Source: authors own compilation from primary data

Over all Ranking (Outcome of statistical analysis):

\begin{tabular}{|l|c|}
\hline \multicolumn{1}{|c|}{ Attributes } & Ranking \\
\hline Variety in menu & 1 \\
\hline Taste of Food & 2 \\
\hline food quality & 3 \\
\hline Décor & 4 \\
\hline Location & 5 \\
\hline Efficient service & 6 \\
\hline Friendly, Polite and Helpful staff & 7 \\
\hline Seating capacity & 8 \\
\hline Staff appearance & 9 \\
\hline General Excitement a place generates & 10 \\
\hline Waiting time for the order & 11 \\
\hline Sympathetic handling of complaints & 12 \\
\hline
\end{tabular}

Source: authors own compilation from primary data

As per the given data and its interpretation, variety in menu is evident to be the most important attribute for the customers. It is followed by Taste of Food, food quality, décor, location, efficient services, Friendly, Polite and Helpful staff, seating capacity, staff appearance, General Excitement a place generates, waiting time for the order and the least important attribute for the respondents is Sympathetic handling of complaints.

Section 4: Analysis of the 'Most Influencing Parameters' - Analysis of the most Influencing parameters on the basis of Mean and Standard Deviation (SD)

\begin{tabular}{|l|l|l|l|}
\hline S.No. & \multicolumn{1}{|c|}{ Parameters } & \multicolumn{1}{|c|}{ Mean } & $\begin{array}{c}\text { Standard } \\
\text { deviation }\end{array}$ \\
\hline 1 & Taste of the food & 3.66 & 0.87 \\
\hline 2 & Variety in menu & 4.2 & 0.85 \\
\hline 3 & Food quality & 3.62 & 0.83 \\
\hline 4 & Friendly, polite and helpful staff & 2.76 & 1.06 \\
\hline 5 & Efficient service & 3.2 & 1.06 \\
\hline 6 & Sympathetic handling of complaints & 1.88 & 1.09 \\
\hline 7 & Décor & 3.7 & 0.83 \\
\hline 8 & Staff appearance & 2.68 & 1.07 \\
\hline 9 & General excitement a place generates & 2.88 & 1.06 \\
\hline
\end{tabular}


DOI: 10.14807/ijmp.v8i4.657

\begin{tabular}{|l|l|l|l|}
\hline 10 & Seating capacity & 3.5 & 0.86 \\
\hline 11 & Waiting time for the order & 2.46 & 0.73 \\
\hline
\end{tabular}

Source: authors own compilation from primary data

Fast food joints are already having a good following with customers in terms of Taste of the food, Variety in menu, Food quality, Décor, Seating capacity and Waiting time for the order Nirula's has to work on improving Friendliness, politeness and helpfulness in staff, efficient service, Sympathetic handling of complaints, Staff appearance and General excitement a place generates.

\section{Section 5: Hypothesis Testing}

\section{Frequency of visiting Fast food joints}

Ho: Frequency of visiting fast food joints is independent of age of respondents

$\mathrm{H1}$ : Frequency of visiting fast food joints is dependent of age of respondents

\section{With whom visiting Fast food joints}

Ho: There is no significant relationship between age of respondents and with whom customers visit fast food joints.

$\mathrm{H} 1$ : There is significant relationship between age of respondents and with whom customers visit fast food joints

\section{Amount spent per visit}

Ho : age of respondents does not leave considerable impact on amount spent per visit.

H1: age of respondents leaves considerable impact on amount spent per visit.

\section{Preferable time to visit the fast food joints}

Ho : Preferable time to visit the fast food joints does not depend on the age of the respondents

H1 : Preferable time to visit the fast food joints depends on the age of the respondents

\section{How came to know about fast food joints}

Ho: Awareness about fast food joints is independent of age of respondents

$\mathrm{H} 1$ : Awareness about fast food joints is dependent of age of respondents 


\section{Preparations of food}

Ho: age of respondents does not leave considerable impact on types of preparations served at fast food joints.

$\mathrm{H} 1$ : age of respondents leaves considerable impact on types of preparations served at fast food joints.

\section{Reasons for patronizing a particular fast food joint}

Ho: There is no significant relationship between age of respondents and reasons of patronizing a particular fast food joint.

$\mathrm{H} 1$ : There is significant relationship between age of respondents and reasons of patronizing a particular fast food joint.

\section{Effective Promotional Activity to attract customers}

Ho: Effective Promotional Activity to attract customers is independent of age of respondents

H1: Effective Promotional Activity to attract customers is dependent of age of respondents

\section{Perception of overall quality provided by fast food joints}

Ho: age of respondents does not leave considerable impact on overall quality of services provided by fast food joints.

$\mathrm{H} 1$ : age of respondents leaves considerable impact on overall quality of services provided by fast food joints.

\section{Like to recommend to other}

Ho: There is no significant relationship between age of respondents and recommending their favorite fast food joint to others.

$\mathrm{H} 1$ : There is significant relationship between age of respondents and recommending their favorite fast food joint to others. 
INDEPENDENT JOURNAL OF MANAGEMENT \& PRODUCTION (IJM\&P)

http://www.ijmp.jor.br

v. 8, n. 4, October - December 2017

ISSN: 2236-269X

DOI: 10.14807/ijmp.v8i4.657

\begin{tabular}{|c|c|c|c|c|c|}
\hline $\begin{array}{l}\text { Demographic } \\
\text { variable }\end{array}$ & Question Variable & $\begin{array}{l}\text { Chi- } \\
\text { square } \\
\text { value }\end{array}$ & $\begin{array}{c}\text { P- } \\
\text { value } \\
\text { of chi- } \\
\text { square } \\
\text { test }\end{array}$ & $\begin{array}{l}\text { Hypothesis } \\
\text { testing }\end{array}$ & $\begin{array}{c}\text { Hypothesis } \\
\text { accepted/rejected }\end{array}$ \\
\hline \multirow{10}{*}{ Age } & Frequency of visiting Fast food joints & 10.16 & 0.3372 & $\alpha<p$ & $\begin{array}{l}\text { Null hypothesis Ho } \\
\text { is accepted }\end{array}$ \\
\hline & With whom visiting Fast food joints & 17.82 & 0.1211 & $\alpha<p$ & $\begin{array}{l}\text { Null hypothesis Ho } \\
\text { is accepted }\end{array}$ \\
\hline & Amount spent per visit & 8.27 & 0.2187 & $\alpha<p$ & $\begin{array}{l}\text { Null hypothesis Ho } \\
\text { is accepted }\end{array}$ \\
\hline & Preferable time to visit the fast food joints & 2.74 & 0.8398 & $\alpha<p$ & $\begin{array}{l}\text { Null hypothesis Ho } \\
\text { is accepted }\end{array}$ \\
\hline & How came to know about fast food joints & 5.25 & 0.5113 & $\alpha<p$ & $\begin{array}{l}\text { Null hypothesis Ho } \\
\text { is accepted }\end{array}$ \\
\hline & Preparations of food & 1.55 & 0.9558 & $\alpha<p$ & $\begin{array}{l}\text { Null hypothesis Ho } \\
\text { is accepted }\end{array}$ \\
\hline & Reasons for patronizing a particular fast food joint & 12.91 & 0.1665 & $\alpha<p$ & $\begin{array}{l}\text { Null hypothesis Ho } \\
\text { is accepted }\end{array}$ \\
\hline & Effective Promotional Activity to attract customers & 8.02 & 0.5317 & $\alpha<p$ & $\begin{array}{l}\text { Null hypothesis Ho } \\
\text { is accepted }\end{array}$ \\
\hline & $\begin{array}{l}\text { Perception of overall quality provided by fast food } \\
\text { joints }\end{array}$ & 42.13 & 0.0000 & $\alpha>p$ & $\begin{array}{l}\text { Alternate } \\
\text { hypothesis } \mathrm{H} 1 \text { is } \\
\text { accepted }\end{array}$ \\
\hline & Like to recommend to other & 15.39 & 0.0015 & $\alpha>p$ & $\begin{array}{l}\text { Alternate } \\
\text { hypothesis } \mathrm{H} 1 \text { is } \\
\text { accepted }\end{array}$ \\
\hline \multirow{10}{*}{ Gender } & Frequency of visiting Fast food joints & 0.85 & 0.8363 & $\alpha<p$ & $\begin{array}{l}\text { Null hypothesis Ho } \\
\text { is accepted }\end{array}$ \\
\hline & With whom visiting Fast food joints & 2.07 & 0.7218 & $\alpha<p$ & $\begin{array}{l}\text { Null hypothesis Ho } \\
\text { is accepted }\end{array}$ \\
\hline & Amount spent per visit & 4.67 & 0.0966 & $\alpha<p$ & $\begin{array}{l}\text { Null hypothesis Ho } \\
\text { is accepted }\end{array}$ \\
\hline & Preferable time to visit the fast food joints & 1.37 & 0.5033 & $\alpha<p$ & $\begin{array}{l}\text { Null hypothesis Ho } \\
\text { is accepted }\end{array}$ \\
\hline & How came to know about fast food joints & 16.81 & 0.0002 & $\alpha>p$ & $\begin{array}{l}\text { Alternate } \\
\text { hypothesis } \mathrm{H} 1 \text { is } \\
\text { accepted }\end{array}$ \\
\hline & Preparations of food & 4.57 & 0.1015 & $\alpha<p$ & $\begin{array}{l}\text { Null hypothesis Ho } \\
\text { is accepted }\end{array}$ \\
\hline & Reasons for patronizing a particular fast food joint & 0.30 & 0.9592 & $\alpha<p$ & $\begin{array}{l}\text { Null hypothesis Ho } \\
\text { is accepted }\end{array}$ \\
\hline & Effective Promotional Activity to attract customers & 0.19 & 0.9788 & $\alpha<p$ & $\begin{array}{l}\text { Null hypothesis Ho } \\
\text { is accepted }\end{array}$ \\
\hline & $\begin{array}{l}\text { Perception of overall quality provided by fast food } \\
\text { joints }\end{array}$ & 4.88 & 0.2997 & $\alpha<p$ & $\begin{array}{l}\text { Null hypothesis Ho } \\
\text { is accepted }\end{array}$ \\
\hline & Like to recommend to other & 0.41 & 0.5196 & $\alpha<p$ & $\begin{array}{l}\text { Null hypothesis Ho } \\
\text { is accepted }\end{array}$ \\
\hline \multirow{6}{*}{ Occupation } & Frequency of visiting Fast food joints & 11.75 & 0.2276 & $\alpha<p$ & $\begin{array}{l}\text { Null hypothesis Ho } \\
\text { is accepted }\end{array}$ \\
\hline & With whom visiting Fast food joints & 17.91 & 0.1182 & $\alpha<p$ & $\begin{array}{l}\text { Null hypothesis Ho } \\
\text { is accepted }\end{array}$ \\
\hline & Amount spent per visit & 15.07 & 0.0197 & $\alpha>p$ & $\begin{array}{l}\text { Alternate } \\
\text { hypothesis } \mathrm{H} 1 \text { is } \\
\text { accepted }\end{array}$ \\
\hline & Preferable time to visit the fast food joints & 1.99 & 0.9201 & $\alpha<p$ & $\begin{array}{l}\text { Null hypothesis Ho } \\
\text { is accepted }\end{array}$ \\
\hline & How came to know about fast food joints & 5.44 & 0.4887 & $\alpha<p$ & $\begin{array}{l}\text { Null hypothesis Ho } \\
\text { is accepted }\end{array}$ \\
\hline & Preparations of food & 5.14 & 0.5257 & $\alpha<p$ & $\begin{array}{l}\text { Null hypothesis Ho } \\
\text { is accepted }\end{array}$ \\
\hline
\end{tabular}


INDEPENDENT JOURNAL OF MANAGEMENT \& PRODUCTION (IJM\&P)

http://www.ijmp.jor.br

v. 8, n. 4, October - December 2017

ISSN: 2236-269X

DOI: 10.14807/ijmp.v8i4.657

\begin{tabular}{|c|c|c|c|c|c|}
\hline & Reasons for patronizing a particular fast food joint & 22.50 & 0.0074 & $\alpha>p$ & $\begin{array}{l}\text { Alternate } \\
\text { hypothesis } \mathrm{H} 1 \text { is } \\
\text { accepted }\end{array}$ \\
\hline & Effective Promotional Activity to attract customers & 14.26 & 0.1131 & $\alpha<p$ & $\begin{array}{l}\text { Null hypothesis Ho } \\
\text { is accepted }\end{array}$ \\
\hline & $\begin{array}{l}\text { Perception of overall quality provided by fast food } \\
\text { joints }\end{array}$ & 10.66 & 0.5575 & $\alpha<p$ & $\begin{array}{l}\text { Null hypothesis Ho } \\
\text { is accepted }\end{array}$ \\
\hline & Like to recommend to other & 3.73 & 0.2917 & $\alpha<p$ & $\begin{array}{l}\text { Null hypothesis Ho } \\
\text { is accepted }\end{array}$ \\
\hline \multirow{10}{*}{ Income } & Frequency of visiting Fast food joints & 11.07 & 0.2706 & $\alpha<p$ & $\begin{array}{l}\text { Null hypothesis Ho } \\
\text { is accepted }\end{array}$ \\
\hline & With whom visiting Fast food joints & 34.30 & 0.0006 & $\alpha>p$ & $\begin{array}{l}\text { Alternate } \\
\text { hypothesis } \mathrm{H} 1 \text { is } \\
\text { accepted }\end{array}$ \\
\hline & Amount spent per visit & 17.65 & 0.0072 & $\alpha>p$ & $\begin{array}{l}\text { Alternate } \\
\text { hypothesis } \mathrm{H} 1 \text { is } \\
\text { accepted }\end{array}$ \\
\hline & Preferable time to visit the fast food joints & 1.24 & 0.9744 & $\alpha<p$ & $\begin{array}{l}\text { Null hypothesis Ho } \\
\text { is accepted }\end{array}$ \\
\hline & How came to know about fast food joints & 6.80 & 0.3389 & $\alpha<p$ & $\begin{array}{l}\text { Null hypothesis Ho } \\
\text { is accepted }\end{array}$ \\
\hline & Preparations of food & 7.93 & 0.2428 & $\alpha<p$ & $\begin{array}{l}\text { Null hypothesis Ho } \\
\text { is accepted }\end{array}$ \\
\hline & Reasons for patronizing a particular fast food joint & 15.12 & 0.0875 & $\alpha<p$ & $\begin{array}{l}\text { Null hypothesis Ho } \\
\text { is accepted }\end{array}$ \\
\hline & Effective Promotional Activity to attract customers & 16.50 & 0.0571 & $\alpha<p$ & $\begin{array}{l}\text { Null hypothesis Ho } \\
\text { is accepted }\end{array}$ \\
\hline & $\begin{array}{l}\text { Perception of overall quality provided by fast food } \\
\text { joints }\end{array}$ & 24.37 & 0.0181 & $\alpha>p$ & $\begin{array}{l}\text { Alternate } \\
\text { hypothesis } \mathrm{H} 1 \text { is } \\
\text { accepted }\end{array}$ \\
\hline & Like to recommend to other & 6.53 & 0.0881 & $\alpha<p$ & $\begin{array}{l}\text { Null hypothesis Ho } \\
\text { is accepted }\end{array}$ \\
\hline \multirow{11}{*}{ Education } & Frequency of visiting Fast food joints & 7.25 & 0.6105 & $a<p$ & $\begin{array}{l}\text { Null hypothesis Ho } \\
\text { is accepted }\end{array}$ \\
\hline & With whom visiting Fast food joints & 21.56 & 0.0427 & $\alpha>p$ & $\begin{array}{l}\text { Alternate } \\
\text { hypothesis } \mathrm{H} 1 \text { is } \\
\text { accepted }\end{array}$ \\
\hline & Amount spent per visit & 7.41 & 0.2839 & $\alpha<p$ & $\begin{array}{l}\text { Null hypothesis Ho } \\
\text { is accepted }\end{array}$ \\
\hline & Preferable time to visit the fast food joints & 9.21 & 0.1619 & $\alpha<p$ & $\begin{array}{l}\text { Null hypothesis Ho } \\
\text { is accepted }\end{array}$ \\
\hline & How came to know about fast food joints & 3.84 & 0.6979 & $\alpha<p$ & $\begin{array}{l}\text { Null hypothesis Ho } \\
\text { is accepted }\end{array}$ \\
\hline & Preparations of food & 4.98 & 0.5460 & $\alpha<p$ & $\begin{array}{l}\text { Null hypothesis Ho } \\
\text { is accepted }\end{array}$ \\
\hline & Reasons for patronizing a particular fast food joint & 8.68 & 0.4671 & $\alpha<p$ & $\begin{array}{l}\text { Null hypothesis Ho } \\
\text { is accepted }\end{array}$ \\
\hline & Effective Promotional Activity to attract customers & 2.88 & 0.9687 & $a<p$ & $\begin{array}{l}\text { Null hypothesis Ho } \\
\text { is accepted }\end{array}$ \\
\hline & $\begin{array}{l}\text { Perception of overall quality provided by fast food } \\
\text { joints }\end{array}$ & 10.92 & 0.5352 & $\alpha<p$ & $\begin{array}{l}\text { Null hypothesis Ho } \\
\text { is accepted }\end{array}$ \\
\hline & Like to recommend to other & 2.84 & 0.4154 & $\alpha<p$ & $\begin{array}{l}\text { Null hypothesis Ho } \\
\text { is accepted }\end{array}$ \\
\hline & Frequency of visiting Fast food joints & 12.96 & 0.0436 & $\alpha>p$ & $\begin{array}{l}\text { Alternate } \\
\text { hypothesis } \mathrm{H} 1 \text { is }\end{array}$ \\
\hline
\end{tabular}


INDEPENDENT JOURNAL OF MANAGEMENT \& PRODUCTION (IJM\&P)

http://www.ijmp.jor.br

v. 8, n. 4, October - December 2017

ISSN: 2236-269X

DOI: 10.14807/ijmp.v8i4.657

\begin{tabular}{|c|c|c|c|c|c|}
\hline \multirow{10}{*}{$\begin{array}{l}\text { Dietary } \\
\text { preference }\end{array}$} & & & & & accepted \\
\hline & With whom visiting Fast food joints & 21.81 & 0.0053 & $\alpha>p$ & $\begin{array}{l}\text { Alternate } \\
\text { hypothesis } \mathrm{H} 1 \text { is } \\
\text { accepted }\end{array}$ \\
\hline & Amount spent per visit & 4.42 & 0.3518 & $\alpha<p$ & $\begin{array}{l}\text { Null hypothesis Ho } \\
\text { is accepted }\end{array}$ \\
\hline & Preferable time to visit the fast food joints & 4.75 & 0.3135 & $\alpha<p$ & $\begin{array}{l}\text { Null hypothesis Ho } \\
\text { is accepted }\end{array}$ \\
\hline & How came to know about fast food joints & 3.32 & 0.5055 & $\alpha<p$ & $\begin{array}{l}\text { Null hypothesis Ho } \\
\text { is accepted }\end{array}$ \\
\hline & Preparations of food & 78.48 & 0.0000 & $\alpha>p$ & $\begin{array}{l}\text { Alternate } \\
\text { hypothesis } \mathrm{H} 1 \text { is } \\
\text { accepted }\end{array}$ \\
\hline & Reasons for patronizing a particular fast food joint & 7.10 & 0.3110 & $\alpha<p$ & $\begin{array}{l}\text { Null hypothesis Ho } \\
\text { is accepted }\end{array}$ \\
\hline & Effective Promotional Activity to attract customers & 7.41 & 0.2844 & $\alpha<p$ & $\begin{array}{l}\text { Null hypothesis Ho } \\
\text { is accepted }\end{array}$ \\
\hline & $\begin{array}{l}\text { Perception of overall quality provided by fast food } \\
\text { joints }\end{array}$ & 11.77 & 0.1614 & $\alpha<p$ & $\begin{array}{l}\text { Null hypothesis Ho } \\
\text { is accepted }\end{array}$ \\
\hline & Like to recommend to other & 0.34 & 0.8399 & $\alpha<p$ & $\begin{array}{l}\text { Null hypothesis Ho } \\
\text { is accepted }\end{array}$ \\
\hline
\end{tabular}

Source: authors own compilation from primary data

\section{MAJOR FINDINGS}

The majority of respondents (40\%) confirmed that they visit fast food joints with their friends. Most of the respondents (42\%)spend between INR 500 and INR 1000 per head in each visit. The majority of respondents with 50\% prefer to visit fast food joints in the evening. The majority of respondents (56\%) have come to know about fast food joints owing to its visible outlets.

Most of the respondents (44\%) like both vegetarian and non-vegetarian preparations of food. The greater part of respondents with $50 \%$ patronize fast food joints because of its location. The majority of customers with $42 \%$ get attracted to fast food joints because of their home delivery promotional activity. Most of the customers i.e. $42 \%$ perceive the quality of food provided by fast food joints as good.

The greater part of customers i.e. $70 \%$ are positive about recommending fast food joints they visit to others. Variety in menu is evident to be the most important attribute for the customers and the least important attribute for the respondents is Sympathetic handling of complaints. Fast food joints have to work on improving friendliness, politeness and helpfulness in staff, efficient service, sympathetic handling of complaints, staff appearance and general excitement a place generates. 


\section{CONCLUSION}

In today's world, Fast food is something that almost everyone, right from kids to the oldies, loves, and talks about fast food. Fast food is one of the world's fastest growing food types. At the backdrop of modernization, globalization and privatization has brought in innumerable MNC and Desi brands to the Indian market.

Fast food joints are enjoying enormous popularity among people of all age groups. As the disposable income, has tremendously increased, this trend has meteorically raised. Fast food joints commit to provide its customers with good food and services. The competition in the market is quite stiff and to shine above the competition, fast food joints have to extensively work upon some of its offerings in terms of overall delivery. Variety in menu, taste and quality of food, Decor, seating capacity and waiting time for the order are forte of fast food joints.

Fast food joints have to still prove themselves in terms of more efficient services and better handling of complaints. The staff's appearance and their friendly and polite approach are to be given due importance as it is being rated one of its, bleak aspects.

Further, proper promotion and advertising should be meticulously taken care of so as to target a wider no of prospects. Price competitiveness should also be taken into account as a no of competitors are coming out with low priced offerings.

\section{REFERENCE}

ASHOK KUMAR, D.; SANKARAARAYANAN, S. (n.d.) Decision making styles of Indian youth toward organized fast food outlets. Retrieve fromhttp://www.aimsinternational.org/aims12/12A-CD/PDF/K484-final.pdf

BARRY, B.; JOEL, E.; MINI, M. (2013) Retail management (11th ed.). Pearson Publication.

BELK, R. W. (2011) Research in Consumer Behavior. Bingley, U.K.: Emerald Group Publishing Limited.

DANI, V.; PABALKAR, V. (2013, September) Exploring of consumer behavior towards fast food industry: a case study on Pune. Indian journal of applied research, v. 3, n. 9. Retrieve from https://www.worldwidejournals.com/indianjournal-of-applied-research-(IJAR)/file.php?val=September

DEIVANAI, P. (2013) A study of consumer behavior towards fast food products with special reference to Domino's Pizza. International research journal of business and management, n. 5. 
GOYAL, P. (2015, March) A study of quick service restaurants with reference to consumers' perception and their behavior in Delhi NCR Region. International journal of science, technology and management, v. 4, n. 1. Retrieve from https://www.ijstm.com/images/short_pdf/1425961743_525.pdf

KERIN; HARTLEY (2016) Marketing: The Core, 6th ed., McGraw Hill Higher Education.

KHAN, M. A. (2006) Consumer Behaviour and Advertising Management. New Delhi: New Age International.

KPMG \& FCCI. (2016, November) India's food service industry: growth recipe: consumer market. Retrieve from https://assets.kpmg.com/content/dam/kpmg/in/pdf/2016/11/Indias-food-service.pdf LEON, S.; KANUK, L.; KUMAR RAMES, S. (2013) Consumer behavior. (10th ed.). Pearson Publication

MILLER, R. K.; WASHINGTON, K. D.; RICHARD, K.; MILLER, A. (2014) Consumer Behavior 2014. Loganville, GA: Richard K. Miller \& Associates.

NEERU, K. (2014) Principles of marketing. PHI Learning Pvt. Ltd. NOEL, C.; SIDDHARTHA, S. (2014) Managing marketing: an applied approach. India: Wiley India Pvt. Ltd.

KOTLER, P.; KEVIN, K.; ABRAHAM, K.; MITHILESHWAR, J. (2014) Marketing management. (14th ed.). Pearson Publication

KOTLER, P.; ARMSTRONG, G. (2016) Principles of Marketing, 16th ed., Pearson Education limited

PRABHAVATI, Y.; KRISHNA KISHORE, N. T.; RAMESH KUMAR, M. (2014). Consumer preference and spending pattern in Indian fast food industry. International journal of scientific and research publications, v. 4, n. 2.

PR NEWSWIRE. (2015, May 27) India fast food market report 2015-2020: market is expected to grow at a CAGR of 18\%. Retrieve from http://www.prnewswire.com/news-releases/india-fast-food-market-report-2015--2020-market-is-expected-to-grow-at-a-cagr-of-18-505221141.html

RAJNEESH, K. (2014) consumer behaviour. Oxford University Press. 